\title{
An-Natiq
}

Jurnal Kajian Islam Interdisipliner

Volume 01 Nomor 02 Tahun 2021

e-ISSN: 2777-0176 | p-ISSN: 2798-0200

\section{PENDEKATAN SEJARAH DALAM STUDI EKONOMI ISLAM}

\author{
Hasnidar Yuslin \\ Universitas Islam Negeri Sunan Kalijaga Yogyakarta \\ e-mail: hasnidaryuslin@gmail.com
}

\begin{abstract}
This article focuses on discussing the historical approach in the study of Islamic economics, starting with Islamic economics which has become an interesting study for many groups. Islamic economics is not only understood historically but has also become a complex phenomenon. Islamic economics does not only consist of a series of norms for how a person makes decisions, but Islamic economics has become a scientific discipline and a legitimate part of world civilization. Economic studies in Islam itself as one of the civilizations that have a major contribution, the study of economics also has its place among Muslim scholars from time to time. Therefore, to study and approach Islamic economics not only in one aspect, but interdisciplinary methods and approaches are also needed that are in line with Islamic history itself.
\end{abstract}

Keywords: Historical and Study of Islamic Economics

\section{A. Pendahuluan}

Sejak Islam muncul sebenarnya Ekonomi Islam telah ada, ekonomi Islam hadir tidak hanya sebagai suatu disiplin ilmu tersendiri, akan tetapi juga menjadi bagian integral dari agama Islam itu sendiri. Islam sebagai ajaran yang lengkap hingga dapat memberikan dalam aktivitas manusia termasuk aktivitas ekonomi (Jaelani, n.d.). Pemikiran ekonomi Islam sendiri telah muncul sejak abad ke-8 secara parsial, seperti: peran negara dalam kaidah berdaganag, mekanisme pasar, dan lain-lain. Akan tetapi pemikiran ekonomi Islam yang lebih komprehensif dimulai pada pertengahan abad-20 yang kemudian semakin berkembang sejak dua dasawarsa terakhir. Salah satu sudut pandang yang dikembangkankan dalam pengkajian Ekonomi Islam itu yakni pendekatan sejarah (Sukirno, 2016).

Dari sudut pandang itu, ekonomi Islam dapat dipahami secara eksplisit dalam persoalan kehidupan sehari-hari secara keseluruhan yang bersifat ekonomi baik oleh setiap individu, perusahaan maupun masyarakat. Perkembangan di masa sekarang yang dapat dilakukan ialah dengan bercermin pada persoalan-persoalan kebajikan di masa lampau yang memungkinkan dapat dijadikan sebagai rujukan dalam menjawab persoalan yang terjadi masa kini (Sukirno, 2016). Oleh karena itu, sejarah memiliki arti penting bagi manusia, yang dapat dijadikan sebagai pengetahuan atau sebatas dijadikan pendekatan untuk mempelajari ekonomi Islam. Apabila sejarah dijadikan sebagai suatu pendekatan untuk mempelajari ekonomi Islam, maka sudutnya pandang yang digunakan yakni menatar peristiwa atau 
pemikiran-pemikiran di masa lampau, sebab sejarah menjadi metodologi ekonomi Islam yang menekankan pada pemahaman di berbagai dimensi waktu (Ifan, 2008). Olehnya itu, penelitian tentang persoalan ekonomi berdasarkan pendekatan sejarah harus dilihat dari proses dan perkembangannya. Pendekatan sejarah inilah yang semestinya dikembangkan dalam penelitian persoalan ekonomi.

\section{Ekonomi Islam sebagai Suatu Ilmu dan Norma}

Dalam mempelajari ekonomi Islam ada dua hal yang sangat penting untuk dipahami yakni pemahaman tentang terminologi ekonomi positif dan ekonomi normatif. Ekonomi positif yang fokus menekanakan pada senyatanya terjadi atau realitas hbungan ekonomi, sedangkan sementara ekonomi normatif menekankan pada apa yang seharusnya dilakukan atau apa yang semestinya terjadi. Keharusan ini berdasar atas nilai atau norma tertentu, baik secara implisit maupun eksplisit (Karim, 2012). Misalnya pernyataan ekonomi postif yakni kemiskinan di negara berkembang memang semakin buruk, sedangkan pernyataan ekonomi normatif ialah kemiskinan yang terjadi di negara berkembang tidak seharusnya semakin memburuk.

Ilmu ekonomi konvensional secara tegas memisahkan antara aspek positif dan aspek normatif. Pemisahan aspek ini memberikan implikasi fakta bahwa ekonomi menjadi sesuatu yang independen terhadap norma, tiadanya kausalitas antara norma dengan fakta. Dengan kata lain, realitas ekonomi bersifat independen dan karenanya bersifat objektif kemudian akhirnya berlaku secara universal. Mislanya, pada hukum yang menyatakan ketika harga suatu barang mengalami peningkatan, maka jumlah barang yang ditawarkan juga mengalami peningkatan (Indonesia, 2012).

Pemisahan ilmu ekonomi positif dan normatif pada dasarnya bertentangan dengan karakteristik dasar ilmu sosial dan fakta empiris dalam perekonomian dunia. Ilmu sosial yang didasarkan dan diawali pada nilai-nilai tertentu baik pada aspek ontologis, epistemologis maupun aksiologis. Dengan demikian, tidak ada ilmu ekonomi yang bebas nilai. Pada dasarnya pendikotomian positif dan normatif ditolak dalam ekonomi Islam dengan dasar pandangan Islam yang meyakini perilaku sosial manusia tidak terjadi dengan sendirinya. Perilaku tersebut bukanlah sesuatu yang bebas nilai, sebab manusia memiliki kehendak, kecenderungan dan perilaku yang sangat dipengaruhi oleh nilai atau etika yang diyakininya, serta pandangannya terhadap kehidupan ini. Selain itu, interaksi antara variabel dan kejadian lain yang tak terpisahakan secara mekanis satu dengan lainnya juga mempengaruhi kejadian dalam ekonomi. Dengan kata lain, terdapat suatu multirelasi dan multikausalitas yang kompleks antara berbagai variabel dalam kejadian sosial, sedangkan kejadian ekonomi hanya menjadi salah satunya. Jadi, 
dapat dikatakan bahwa terdapat keterkaitan antara aspek positif dan normatif, aspek ini tidak dapat didikotomisasikan secara kaku (Natadipura, 2015).

Ekonomi Islam pun pada dasarnya mengendepankan pendekatan integratif antara normatif dan positif. Islam menempatkan etika pada posisi yang tinggi dalam sebuah nilai. Etika ini menjadi kerangka awal dalam ilmu ekonomi dengan tujuan penjelasan, pemahaman dan penilaian harus dilakukan atas dasar kerangka ilmu sosial secara integral tanpa mendikotomikan antara etika dan realita. Padangan Islam tentang integrasi etika dan realita tentu berbeda dengan pemahaman Max Weber tentang Wertfrei. Dalam Islam, etikalah yang harus menguasai ilmu ekonomi bukan sebaliknya. Hidup seorang manusia dalam pandangan Islam pun harus dituntun oleh syariat Islam secara keseluruhan dan inilah yang menjaidi misi utama eksistensi manusia di muka bumi. Perangkat lengkap telah ada dalam syariah Islam tentang manhaj al-hayah (sistem kehidupan) dan wasilah al-hayah (sarana kehidupan). Ekonomi Islam akan didapatkan melalui integrasi norma dan ilmu ekonomi (Indonesia, 2012).

Ekonomi Islam tidak hanya dipandang sebagai deskripsi empiris atas perilaku umat Islam, akan tetapi menciptakan suatu perekonomian yang mampu membawa manusia dalam mencapai falah (Natadipura, 2015). Meskipun secara realitas keberadaan studi ilmu ekonomi Islam tidak terbantahkan, akan tetapi dikalangan para ekono masih terjadi perdebatan pada permasalahan dugaan bahwa ekonomi Islam itu bersifat normatif semata dan karenanya tidak bisa dianggap sebagai disiplin ilmu tersendiri. Oleh karena itu, diperlukan metodologi ekonomi Islam sebagai solusi untuk permasalahan tersebut.

\section{B. Metodologi Ekonomi Islam}

Metodologi dijadikan sebagai aspek yang penting dalam membantu mencari kebenaran. Islam meyakini Al-Qur'an dan Sunnah menjadi sumber kebenaran mutlak yang berlaku untuk setiap aspek kehidupan pada setiap ruang dan waktu (Aziz, 2008). Sumber kebenaran ini menjadi dasar pengetahuan dan kemampuan manusia dalam proses pengambilan keputusan ekonomi. Keputusan ekonomi ini disebut sebagai rasionalitas Islam. Perilaku para pelaku ekonomi menjadi asumsi dalam setiap analisis ekonomi. Secara umum sering kali diasumsikan dalam pengambilan keputusan ekonomi, misalnya setiap pelaku ekonomi harus berpikir, bertindak dan bersikap secara rasional. Terminologi rasionalitas ini sangat longgar yang dibangun dalam argumentasi apapun, selama hal tersebut memenuhi kaidahkaidah logika yang ada dan dapat diterima akal sehingga dianggap sebagai bagian dari ekspresi rasionalitas (Kahf, 1995). Olehnya itu, dibutuhkan aksioma dalam terminologi rasionalitas atas dasar kaidah-kaidah secara universal yang dapat diterima dan tidak perlu dilakukan pengujian untuk membuktikan kebenarannya. 
Aksioma ini menjadi acuan dalam pengujian rasionalitas dari suatu argumen atau perilaku yang digali dari nilai-nilai suatu budaya yang bersifat universal. Namun, penafsiran operasional dari nilai-nilai tersebut berdasar pada cara pandang dan berpikir atas budaya yang berlaku dan juga sering kali dipengaruhi oleh situasi dan kondisi lingkungannya. Rasionalitas Islam secara umum dibangun atas dasar aksioma-aksioma yang diderivasikan dari agama Islam. Dengan demikian, dapat ditemukan solusi bahwa ketika dikaji dari segi metodologi yang bersumber dari Alquran dan Sunnah, maka ilmu ekonomi menjadi bagian integral dari ajaran Islam. Ekonomi Islam akan terwujud jika ajaran Islam diyakini dan dilaksanakan secara menyeluruh (Deliarnov, 2009). Ekonomi Islam pun merupakan ilmu yang mempelajari usaha manusia untuk mengelola dan mengalokasikn sumber daya untuk mencapai falah yang berdasar pada prinsip-prinsip serta nilai-nilai Al-quran dan Sunnah (Natadipura, 2015).

\section{Pertumbuhan dan Obyek Studi Ekonomi Islam}

Studi ekonomi Islam dalam kebajikan ekonomi dan praktiknya telah ada sejak masa Rasulullah SAW dan Khulafa Al-Rasyidin. Masa itu dijadikan sebagai contoh empiris bagi para cendekiawan Muslim dalam melahirkan teori-teori ekonominya. Satu salah satu yang menjadi fokus perhatian mereka adalah pada aspek pemenuhan kebutuhan yang menjunjung nilai keadilan, nilai efisiensi, dan kebebasan yang menjadi objek utama dalam pemikiran ekonomi Islam sejak masa awal. Hal ini menuntut sejumlah para ekonom untuk mengembangkan sistem perekenomian yang sejalan dengan prinsip keadilan sosio-ekonomi dan kewajaran. Misi inilah yang akan membawa pesan kepada manusia tentang kebahagiaan, kedamaian, kemakuran dan kesejahteraan (Ayub, 2009).

Studi ekonomi Islam sekarang berkembang hampir di seluruh dunia. Di negara Indonesia itu sendiri studi ekonomi Islam telah berkembang di berbagai kampus seperti di STAIN, IAIN, UIN. Dengan demikian obyek studi ekonomi Islam dapat dikelompokkan menjadi beberapa bagian, yaitu: doktrin dari ajaran Islam itu sendiri, sejarah Islam, aliran dan pemikiran tokoh-tokoh pemikir ekonomi Islam.

\section{Metode dan Pendekatan Sejarah dalam Studi Ekonomi Islam}

Telah disepakati bahwa studi ekonomi Islam merupakan suatu disiplin ilmu, berkenaan dengan hal tersebut maka ada beberapa yang perlu dipahami dalam metode pendekatan sejarah atau pemikiran yakni peristiwa atau pemikiran, sebab dari munculnya peristiwa tersebut dan relevansi peristiwa atau pemikiran tersebut dengan kehidupan sekarang (Kurniawan et al., 2014). Sejarah pemikiran ekonomi Islam menyajikan kajian kehidupan aktivitas ekonomi dalam kehidupan. Ilmu tentang pemikiran ekonomi Islam perlu diuraikan mulai dari diturunkannya ayat ekonomi yang tertuang dalam Al-Qur'an. Seperti aktivitas jual beli dan riba yang 
tertuang dalam surah Al-Baqarah ayat 275 dan 279, pembukuan aktivitas transaksi dalam surah Al-Baqarah ayat 282, tentang pengaturan pencarian, penitipan dan membelanjakan harta dan akad yang tertuang dalam surah Al-A'raf ayat 31, An-Nisa ayat 5 dan ayat 10, Al-Maidah ayat 1 . Selanjutnya perkembangan pemikiran ekonomi Islam diuraikan dalam tiga fase, yaitu: fase dasar-dasar ekonomi Islam, fase kemajuan dan fase stagnasi.

\section{Fase Pertama}

Fase ini menjadi fase awal pemikiran ekonomi Islam abad ke-5 H/11M atau dikenal dengan fase dasar-dasar ekonomi Islam yang dipelopori para fukaha yang kemudian diikuti oleh sufi dan juga filosof. Pemikiran mereka berasal dari orang yang berbeda, akan tetapi seiring berjalannya waktu para ahli harus mempunyai disiplin dasar pengetahuan disiplin tersebut yakni fokus fiqh yang sejalan dengan syariah, konteks ini mereka mendiskusikan fenomena ekonomi dengan tujuan yang tidak terbatas hanya gambaran serta penjelasan fenomena ini, akan tetapi juga mengacu pada Al-quran dan Sunnah yang dikemudian dieksplorasi lebih tajam dalam konsep mashlahah dan mafsadah pada aktivitas ekonomi. Pemikiran ini menekankan pada manfaat atas sesuatu yang diperbolehkan dan kerugiannya ketika melakukan sesuatu yang dilarang oleh Agama. Kajian ekonomi ini mayoritas bersifat normatif pada wawasan positif dalam berbicara tentang kebajikan yang baik, perilaku yang adil serta batasan-batasan yang diperbolehkan dalam kaitannya permasalahan dunia (Wati \& HA, 2020).

Selanjutnya kontribusi pada bidang tasawuf hal yakni menjadi mitra yang baik dan saling menguntungkan serta menolak kekayaan yang berlebihan. Para filosif muslim tetap berlandaskan pada Al-Qur'an dan Sunnah dalam setiap pemikirannya (Jaelani, n.d.). Tokoh-tokoh pemikir ekonomi Islam pada fase pertama diwakili oleh:

a) Zaid bin Ali (80H/738M)

Pemikiran Zaid bin Ali ialah keutungan pada dasarnya dapat diperoleh dari hasil penjualan secara kredit dengan keuntungan sewajarnya dan tidak termasuk riba. Keuntungan dari penjualan ini menjadi bentuk kompensasi dari kemudahan atas barang yang dibutuhkan oleh seorang pembeli (Rahmatullah, 2019).

b) Abu Hanifah $(150 \mathrm{H} / 767 \mathrm{M})$

Abu Hanifah selain menjadi seorang fuqaha, beliau juga merupakan seorang pedagang yang melanjutkan usaha dari ayahnya. Semasa hidupnya, pemikiran beliau yang sangat popular yakni transaksi salam. Transaksi ini memudahkan seseorang dalam perdagangan dimana, seseorang dapat mendapatkan barang yang dibutuhkan dengan melakukan pembayaran dikemudian hari sesuai dengan waktu yang 
disepakati bersama dengan merincikan secara jelas dalam akad seperti kualitas barang, jenis komiditi, kuantitas barang, tempat pengiriman serta waktu (Zatadini \& Ghozali, 2018).

c) Abu Yusuf (182H/798M)

Pemikiran Abu Yusuf dalam ekonomi Islam yakni kitab al-Kharaj yang menekankan pada pemberlakukan pajak dari hasil pertanian daripada pedagangan yang menarik sewa dari lahan pertanian. Menurutnya hal ini dianggap lebih adil dan juga akan memberikan hasil produksi yang lebih banyak (Nurseha, 2018).

d) Al-Syaibani (189H/804M)

Kontribusi pemikiran Al-Syaibani terangkum dalam al-kitab fa arMustathab yang menjelaskan tentang pendapatan dan belanja rumah tangga. Beliau menguraikan lebih jelas tentang konsumsi seorang muslim yang diklasifikasikan dalam empat jenis pekerjaan yakni sewa menyewa, perdagagan, pertanian dan industri (Zamzam, 2016).

e) Ibnu Miskawaih (421H/1030M)

Kontribusi pemikiran Ibnu Miskawaih tentang ekonomi Islam yakni tentang peranan dan pertukaran uang. Menurutnya manusia merupakan makhluk sosial yang tidak bisa hidup sendiri, untuk memenuhi kebutuhan dasar hidupnya, maka mereka bekerjasama serta saling membantu. Olehnya itu mereka membutuhkan kompensasi dan logam dijadikan sebagai mata uang yang dikehendaki orang (Kusumastuti, 2020).

2. Fase Kedua

Pada abad ke-11 sampai 15 fase kedua dimulai yang dikenal dengan fase cemerlang karena meninggalkan warisan intelektual yang sangat kaya. Pada fase ini para cendekiawan Muslim mampu menyusun suatu konsep tentang bagaimana umat seharusnya melakukan aktivitas ekonomi yang tetap berlandaskan pada Al-quran dan Sunnah. Disisi lain, fase ini mereka juga dihadapkan dengan realitas politik yang ditandai oleh dua hal yakni, Pertama: terpecahhnya pusat kekuasaan Bani Abbasiyah dan terbaginya kerajaan yang mayoritas didasarkan pada kekuatan regional dibandingkan dengan kehendak rakyat. Kedua: dekadensi moral dikalangan masyarakat yang mengakibatkan ketimpangan antara di kaya dan si miskin, kemudian maraknya korupsi di kalangan para penguasa (Karim, 2008). Tokoh-tokoh pemikir ekonomi Islam pada fase kedua diwakili oleh:

a) Al-Ghazali $(505 \mathrm{H} / 1111 \mathrm{M})$

Pemikiran Al-Ghazali terfokus pada perilaku individu yang dikaji secara komprehensif dan tetap berlandaskan pada Al-Qur'an, Sunnah, 
Ijma sahabat dan tabi'in serta pandangan para sufi terdahulu. Menurutnya seluruh aktivitas ekonomi harus dilaksanakan sejalan dengan syariah Islam, tidak boleh kikir serta bersifat boros. Lebih lanjut menurut Al-Ghazali, ketika diantara rakyat mengalami kekurangan dan kurang mampu membiayai hidupnya, maka penguasa harus menjamin kesejahteraan dan kenyamanan rakyatnya dengan memberikan pertolongan (Sirajuddin, 2016).

b) Ibnu Taimiyah (728H/1328M)

Ibnu Taimiyah menekankan fondasi moral dalam aktivitas ekonomi, menurutnya dalam transaksi ekonomi keadilan yang tercipta berdasar pada kesepakatan dari semua pihak, kesepakatan ini berdasar pada informasi yang jelas. Moralitas yang dianjurkan agama seprti yang tidak adanya unsur keterpaksaan, kecurangan serta tidak mengambil keuntungan yang merugikan orang lain. Ketika hal tersebut dipatuhi, maka harga pasar pada kondisi yang wajar dan adil (Fasiha, 2017).

c) Al-Syatibi $(790 \mathrm{H} / 1388 \mathrm{M})$

Konsep pemikiran Al-Syatibi dalam ekonomi Islam yakni tentang maslahah yang tujuan utamanya ialah adanya maqashid syariah dalam setiap aktivitas ekonomi baik produksi, konsumsi serta pertukaran yang mencari kemaslahatan. Maslahah menurut Al-Syatibi lebih kepada kemaslahatan dunia dan akhirat yang mendatangkan manfaat dan berkah (Kara, 2012).

d) Ibnu Khaldun $(808 \mathrm{H} / 1404 \mathrm{H})$

Salah satu pemikiran Ibnu Khaldun yang fenomenal yakni kitab AlMuqaddimah yang berisi tentang berbagai aspek kehidupan manusia dan perkembangan ilmu ketika itu. Kitab ini mencoba mendiskusikan tentang ekonomi, sosiologi dan ilmu politik. Dalam persoalan ekonomi Ibnu Khaldun menjelaskan dalam kitabnya bahwa motif ekonomi muncul disebabkan oleh hasrat manusia yang tak terbatas, akan tetapi ketersediaan barang-barang yang memuaskan kebutuhan itu terbatas. Menurutnya untuk memecahkan masalah ini, maka dibutuhkan dua sudut pandang yakni: sudut tenaga seperti tenaga untuk mengerjakan barang-barang dalam memenuhi kebutuhan sendiri dan sudut tenaga untuk mengerjakan barang-barang untuk memenuhi kebutuhan orang banyak. Kemudian sudut penggunaannya seperti kegunaan barang yang dihasilkan hanya kepentingan sendiri dan kepentingan orang banyak, akan tetapi orang yang mengerjakannya tidaklah menjadi tujuan utama (Huda, 2016).

e) Al-Maqrizi (845H/1441M). 
Pemikiran Al-Maqrizi menekankan bahwa negara yang kaya tidak ditentukan oleh jumlah uang yang dimiliki, akan tetapi ditentukan oleh tingkat neraca pembayaran yang positif serta produksi yang produktif. Misalnya suatu negara melakukan aktivitas ekspor, artinya negara tersebut telah memiliki kemampuan berproduksi yang lebih banyak sehingga menunjukkan negara tersebut efisien dalam berpoduksi (Hadi, 2018).

\section{Fase Ketiga}

Pada tahun 1446 sampai 1932 M fase ketiga dimulai yang menjadi fase tertutupnya pintu ijtihad atau dikenal juga sebagai fase stagnasi. Fase ini, para fukaha hanya dapat mengeluarkan fatwa sesuai dengan aturan mahzah masing-masing serta mereka hanya dapat menulis catatan-catatan dari para pendahulunya, akana tetapi masih terdapat pembaharu yang terjadi selama dua abag terakhir yakni sebuah gerakan yang menyeru kembali ke Al-quran dan Sunnah sebagai sumber pedoman hidup (Karim, 2008).

Tokoh-tokoh pemikir ekonomi Islam pada fase ketiga diwakili oleh: Shah Wali Allah (1176H/1762M), Jamaluddin Al-Alghani (1315H/1897M), Muhammad Abduh (1320H/1905M) dan Muhammad Iqbal (1357H/1938M) (Karim, 2012).

Pendekatan sejarah ini menjadi penting dalam memahami studi ekonomi Islam, sebab studi ekonomi sendiri turun dalam situasi yang konkret bahkan berkaitan dengan kondisi sosial kemasyarakatan dan juga dilanjutkan dengan melihat studi ekonomi Islam sebagai norma ajaran yang berkaitan dengan aspek kehidupan manusia. Urgensi dari pendekatan sejarah dalam studi ekonomi Islam antara lain seperti: dijadikan sebagai sarana untuk menemukan sumber pemikiran ekonomi Islam kontemporer, sebagai sandaran atau landasan ketika terulang masalah atau kasus yang serupa dan sebagai alat penguji dalam gagasan ekonomi, khsusnya dalam pertimbangan penentuan kebijakan serta keuangan negara.

\section{Penutup}

Pengkajian ekonomi Islam adalah sebuah disiplin ilmu yang telah ada sejak kemunculan Islam itu sendiri. Dalam sejarah yang panjang pengkajian ekonomi terwujud dalam berbagai kontribusi tokoh-tokoh pemikir ekonomi Islam itu sendiri yang dimulai pada fase pertama hingga fase ketiga. Sebagai objek studi, ekonomi Islam harus didekati dari berbagai aspek multidisiplin ilmu pengetahuan untuk mengurai fenomema kehidupan. Salah satu aspek yang tidak dapat diabaikan begitu saja bagi seseorang yang ingin memahami ekonomi Islam dengan benar ialah dengan menggunakan pendekatan sejarah. Pendekatan sejarah memiliki urgensi 
seperti: sebagai sarana dalam menemukan sumber pemikiran ekonomi Islam yang kontemporer, sebagai landasan atau referensi ketika terulang masalah atau kasus yang serupa dan sebagai alat penguji dalam gagasan ekonomi khsusnya dalam pertimbangan penentuan kebijakan serta keuangan negara.

\section{Daftar Rujukan}

Ayub, M. (2009). Unserstanding Islamic Finance. Jakarta: (P. G. P. Utama (ed.)). Aziz, A. (2008). Ekonomi Islam Analisis Mikro dan Makro. Yogyakarta: Graha Ilmu. Deliarnov. (2009). Perkembangan Pemikiran Ekonomi. Jakarta: Rajawali.

Fasiha. (2017). Pemikiran Ekonomi Abnu Taimiyah. Journal of Islamic Economic Law, 2(2), 111-127.

Hadi, G. (2018). Pemikiran Ekonomi AlMaqrizi. Mpra, 2(87565), 13-25.

Huda, C. (2016). Economic Thought a pioneer of Islamic Economics; Ibn Khaldun. Economica: Journal of Islamic Economics, 4(1), 103.

Ifan, L. (2008). Sejarah Ekonomi Islam. MSI UII. https://master.islamic.uii.ac.id/article/sejarah-ekonomi-islamperkembangan-panjang-realitas-ekonomi-islam/

Indonesia, P. P. dan P. E. I. (P3EI) U. Y. B. S. dengan B. (2012). Ekonomi Islam. Jakarta: PT Raja Grafindo Persada.

Jaelani, A. (n.d.). Sejarah Pemikiran Ekonomi Islam: Kontribusi Sarjana Muslim dalam Pemikiran dan Analisis Ekonomi.

Kahf, M. (1995). Ekonomi Islam. Jakarta: Pustaka Belajar.

Kara, M. (2012). Pemikiran Al-Syatibi Tentang Maslahah.... Assets, 2, 173-184.

Karim, A. A. (2008). Sejarah Pemikiran Ekonomi Islam. Jurnal Al-Iqtishod, 1(1), 452.

Karim, A. A. (2012). Sejarah Pemikiran Ekonomi Islam. Jakarta: PT Raja Grafindo Persada.

Kurniawan, M. A., Rochanah, Suyatmi, Isbakhi, A. F., Adibah, K., Nikmah, S., Achmad, F., Maisyanah, Zulfa, L. N., Ramadhani, R., Wahyudi, D., Rahman, A., Kumaidah, U., Zaienuri, A., Zulqarnain, Susiana, \& Nuryah. (2014). Sejarah Pemikiran dan Peradaban Islam: Dari Masa Klasik, Tengah, hingga Modern. Qoulun Pustaka, 293.

Kusumastuti, A. S. (2020). Konsep Pertukatan dan Peranan Uang Menurut Ibnu Miskawaih. An-Nisbah: Junral Ekonomi Syariah, 07(April), 250-272.

Natadipura, C. (2015). Ekonomi Islam 101.Bandunga: PT Mobidelta Indonesia.

Nurseha, M. A. (2018). Abu Yusuf (Suatu Pemikiran Ekonomi). LABATILA : Jurnal Ilmu Ekonomi Islam, 1(2), 1-16. 
Rahmatullah. (2019). Ekonomi Islam Pada Masa Zayd Bin Ali, Abu Hanifah, Abu Yusuf Dan As Syaibani. Jurnal Manajemen Dan Ekonomi, 2(2), 258-269.

Sirajuddin. (2016). Konsep Pemikiran Ekonomi Al-Ghazali. Laa Maisyir, 3(1), 4660.

Sukirno, S. (2016). Mikro Ekonomi: Teori Pengantar. Jakarta: PT Raja Grafindo Persada.

Wati, F. Y. L., \& HA, M. R. (2020). Pemikiran Ekonomi Islam Pada Fase Pertama

(Zyad Bin Ali Dan Abu Hanifah ). Al Muqayyad, 3(1 Januari-Juni), 106-113.

Zamzam, F. (2016). Pemikiran Ekonomi: Imam Al-Syaibani. 2, 19-28.

Ayub, M. (2009). Unserstanding Islamic Finance. Jakarta: (P. G. P. Utama (ed.)).

Aziz, A. (2008). Ekonomi Islam Analisis Mikro dan Makro. Yogyakarta: Graha Ilmu.

Deliarnov. (2009). Perkembangan Pemikiran Ekonomi. Jakarta: Rajawali.

Fasiha. (2017). Pemikiran Ekonomi Abnu Taimiyah. Journal of Islamic Economic Law, 2(2), 111-127.

Hadi, G. (2018). Pemikiran Ekonomi AlMaqrizi. Mpra, 2(87565), 13-25.

Huda, C. (2016). Economic Thought a pioneer of Islamic Economics; Ibn Khaldun. Economica: Journal of Islamic Economics, 4(1), 103.

Ifan, L. (2008). Sejarah Ekonomi Islam. MSI UII. https://master.islamic.uii.ac.id/article/sejarah-ekonomi-islamperkembangan-panjang-realitas-ekonomi-islam/

Indonesia, P. P. dan P. E. I. (P3EI) U. Y. B. S. dengan B. (2012). Ekonomi Islam. Jakarta: PT Raja Grafindo Persada.

Jaelani, A. (n.d.). Sejarah Pemikiran Ekonomi Islam: Kontribusi Sarjana Muslim dalam Pemikiran dan Analisis Ekonomi.

Kahf, M. (1995). Ekonomi Islam. Jakarta: Pustaka Belajar.

Kara, M. (2012). Pemikiran Al-Syatibi Tentang Maslahah.... Assets, 2, 173-184.

Karim, A. A. (2008). Sejarah Pemikiran Ekonomi Islam. Jurnal Al-Iqtishod, 1(1), 452.

Karim, A. A. (2012). Sejarah Pemikiran Ekonomi Islam. Jakarta: PT Raja Grafindo Persada.

Kurniawan, M. A., Rochanah, Suyatmi, Isbakhi, A. F., Adibah, K., Nikmah, S., Achmad, F., Maisyanah, Zulfa, L. N., Ramadhani, R., Wahyudi, D., Rahman, A., Kumaidah, U., Zaienuri, A., Zulqarnain, Susiana, \& Nuryah. (2014). Sejarah Pemikiran dan Peradaban Islam: Dari Masa Klasik, Tengah, hingga Modern. Qoulun Pustaka, 293.

Kusumastuti, A. S. (2020). Konsep Pertukatan dan Peranan Uang Menurut Ibnu 
Miskawaih. An-Nisbah: Junral Ekonomi Syariah, 07(April), 250-272.

Natadipura, C. (2015). Ekonomi Islam 101.Bandunga: PT Mobidelta Indonesia.

Nurseha, M. A. (2018). Abu Yusuf (Suatu Pemikiran Ekonomi). LABATILA: Jurnal Ilmu Ekonomi Islam, 1(2), 1-16.

Rahmatullah. (2019). Ekonomi Islam Pada Masa Zayd Bin Ali, Abu Hanifah, Abu Yusuf Dan As Syaibani. Jurnal Manajemen Dan Ekonomi, 2(2), 258-269.

Sirajuddin. (2016). Konsep Pemikiran Ekonomi Al-Ghazali. Laa Maisyir, 3(1), 46-60.

Sukirno, S. (2016). Mikro Ekonomi: Teori Pengantar. Jakarta: PT Raja Grafindo Persada.

Wati, F. Y. L., \& HA, M. R. (2020). Pemikiran Ekonomi Islam Pada Fase Pertama (Zyad Bin Ali Dan Abu Hanifah ). Al Muqayyad, 3(1 Januari-Juni), 106-113.

Zamzam, F. (2016). Pemikiran Ekonomi: Imam Al-Syaibani. 2, 19-28.

Zatadini, N., \& Ghozali, M. (2018). Analisis Pemikiran Ekonomi Islam Imam Abu Hanifah. AL-FALAH : Journal of Islamic Economics, 3(1), 29. https://doi.org/10.29240/jie.v3i1.404 